\title{
Green HRM and Green Business: A Proposed Model for Organizational Sustainability
}

\author{
Mohammad Muzahidul Islam (Corresponding author) \\ Department of Management Studies, Patuakhali Science and Technology University \\ Dumki, Patuakhali-8602, Bangladesh \\ Tel: 018-4316-1773E-mail: muzahidhrm@gmail.com
}

Md. Jahidul Islam

Department of Management Studies, Patuakhali Science and Technology University

Dumki, Patuakhali-8602, Bangladesh

\begin{abstract}
A.K.M. Kanak Pervez
Department of Agronomy and Agricultural Extension, University of Rajshahi

Rajshahi-6205, Bangladesh
\end{abstract}

Md. Nur Nabi

College of Humanities and Development Studies

China Agricultural University, China

Department of Finance and Banking, Patuakhali Science and Technology University

Dumki, Patuakhali-8602, Bangladesh

Received: June 15, 2019 Accepted: June 28, 2019 Published: July 25, 2019

doi:10.5296/emsd.v8i3.14926 URL: https://doi.org/10.5296/emsd.v8i3.14926

\begin{abstract}
Nowadays, sustainability is a significant issue of concern to the people of every sphere of society such as the policy makers, researchers, entrepreneurs and corporate leaders to inspect any effective solution in the context of climatic change. Both green business and green
\end{abstract}


Human Resources Management (HRM) are also experiencing successful innovative practices in the modern organization. Considering theseviews, the principalpurpose of this exploration was to discover the significance of both green business and green HRM for ensuring organizational sustainability. For this study, we have collected the required secondary data from various journals, articles and websites. Inmost of the earlier studies, green business functions and green HRM activities are considered separately toward organizational sustainability. In this article, we put forward a green business and green HRM model inclusively for organizationalsustainability in the light of shared value approach throught out the organization.The model is mainly focused on the sustainability of an organization through the help of ensuring green HRM practices and green entrepreneurship development in the industrial world.

Keywords: Green business, Green HRM, Organizational sustainability

\section{Introduction}

Sustainable development is one of the prime concerns to all strata of the human community as there are destructive climatic impacts on human life and this ground policymakers are trying to explore a sustainable solution to minimize these climatic sufferings. According to the Inter governmental Panel on Climate Change (IPCC), the United States and other countries more than 1,300 researchers said that IPCC forecasts a temperature rise of 2.5 to 10 degrees Fahrenheit over the next century(Chettri, 2018). Rising seas and increased coastal flooding, more destructive hurricanes, frequent and intense heat waves, widespread forest death, growing health impacts, heavier precipitation, and flooding, more severe droughts in some areas, increased pressure on groundwater supplies, changing seasons, melting ice, disruptions to food supplies; all are the phenomena of the impact of global climate change. The Great Barrier Reef, Glacier National Park, The Dead Sea, The Amazon, Yamal Peninsula, Maldives, Indonesia are the factual example of the climate change effect (Adger et al., 2009). In a word, sustainable development is a vital point at issue for keeping these worlds safe and sound. In the present era, many organizations are being used to run their business with a green manner, and also the practice of green HRM is remarkable in different organizations. In the twentieth century, green HRM has been the emerging field of research in the organizational study (Stojanoska, 2016). This paper focusedon exploring Green HRM, Green business compliances and organizational sustainability that are described in previous theoretical and empirical research works. According to the Business Dictionary, the green business is "a business working a way that has no harmful effects on the environment, the community, or the economy" (Business Dictionary, n. d).Green HRM can contribute to reducing the harmful carbon. That directs the organization using fewerpapers and so on. Green HRM is an important strategy to make the organization and its resources sustainable(Aravamudhan, 2012). Green human resources means practicing and enhancing consciousness and assurances to the employee in each and every phases in the organization on the subject of sustainability (Hussain, 2018).Researchers found that numerous business and non-business organizations have taken green steps to reestablish their firms and try to protect the environment from disastrouseffect. 
On the other hand, HR professionals are also taking many strategies and policies with a formal and informal way of meeting as environmental responsibilities (Agarwal, 2014). Researcher's suggestion towards the organizations to apply the green manner in the organizations, especially green recruitment, to achieve competitive advantage in the market(Das, 2014). So, green HRM is very much crucial because green HRM focused on different programs, processes, and technical manner that implies in the organization as to abate damaging effects of the environment and progress positive impacts of the environment on the organization(Stojanoska, 2016).

The other widespread term is 'green business' a frequently rising issue about the sustainability of economic growth (Das, 2016). It is a widespread practiceand concomitant by business nowadays. The phase we have passing is the massive concern of using green business concept and activates green business that is pragmatic around the world because the green business is "a business whose practices doesn't inflict negative effects on its surrounding"(Green, 2011).

On the otherhand, this green business is alarmed with the safeguard of the environment excellence(Lee, 2008). So a greenbusiness can sustain the environmental quality that is much more important for preventing the earth from the damages. Many types of research said about this issue. One of them states that this business develops a strategy and takes reasonable steps to protect the earth from hazardous and unsafe effects(Cooney, 2009). Hence, the green organization is more sustainable business against the environmental challenges and has better corporeal settings, eco-friendliness, and profitableness(Croston, 2009).

On 25 September 2015, the UN General Assembly stated the 2030 Agenda for Sustainable Development at the seventieth session.There have 17 Goals with 169 Targets for the next 15 years (Gain, Giupponi, \& Wada, 2016). Sustainability is important, and it means the long term development in a particular phenomenon. Whatever it is the personal-financial condition, family and society condition, business, development of the country, or the environmental condition of the earth and so on. It is a common goal for all people to develop the economic, social and environmental sustainability. World Commission on Environment and Development says, "sustainable development satisfies the needs of the present generation without jeopardizing the ability of future generations to satisfy theirs"(Bombiak \& Marciniuk-Kluska, 2018). The sustainable development is also called as theterm "environmentally-friendly" (Herring, 2000).

Thus, making the organization sustainable for the future, it is important to utilize proper environmental resources thereby retaining and preserving the natural resource of the earth(Rao, Mathapati, \& Amarapur, 2013) and it will help to make successful through green business strategy and green HRM practices as the green HRM and the green business intention is imperative to enhance the organization's sustainable environmental performance.

Business is thoroughly related to the people, society, environment and the earth. So, making the organization eco-friendly, it is essential to do business with green manner. To make the business green, we need to practice green HRM. Green HRM can make a green business organization sustainable. So, it is high time to use proper green HRM policy to make green 
the organization and build world-class sustainable businesses (Aykan, 2017).

This paper is focusedon exploring the past research of both green business and green HRM for ensuring organizational sustainability. And discussed the perception of green business's and green HRM practice's in various issues. Lastly, the study proposed a model of organizational sustainability through green business and green HRM.

\subsection{Rationale of the Study}

People all over the world are very coconscious on the environment as it's going to very bad condition day by day. So, ensuring the environment sustain the industries need to be more concern about the green manner. And industries or the organizations are impacted on the environment directly. Making sure of the organizations green, it must be formed green business and practices green HRM. There have so many researches on the green business and green HRM practices but researcher found fewer researches on making organizational sustainability through both green business and green HRM practices to gether. So, the researchers tried to review the past researches and introduced a new model for making sustainable organization through green business and green HRM. This study is because of awaking of the managers to mark their organization sustainable and that will help by this paper as well as ensuring the green business and green HRM practices.

\subsection{Methodology}

This is an exploratory research based on previous different articles, reports, journal, data related to the topic of the study as green business, green HRM and organizational sustainability. The literatures were reviewed with a systematic way. The study tried to get the subject based information and knowledge and fined the way to make an organization sustainable through green business and green HRM practices from the previous literatures. The study defined some terms related on the subject matter and also suggested a model for ensuring sustainable organization based on the reviewed literatures. Researchers found some articles related on the study and those were selected randomly to fulfil the purpose of the study.

\section{Literature Review}

\subsection{Green HRM}

Nowadays, the organizations are more concern and provide more priority to execute green HRM policy. It is a human resource management process with environment management manner. It represents right image to society and helps to get a competitive advantage. For making an organization sustainable and prosperous through green HRM practices, the organization has to follow some green HRM functions. Many researchers have discussed various functions of green HRM. Researchers found some standard features of green HRM viz. green job design, green human resource planning, green recruitment, green health and safety management(Stojanoska, 2016), green selection, green training and development (Arulrajah, Opatha, \& Nawaratne, 2015), green reward and performance management, andgreen employee's relation (Stojanoska, 2016). 


\subsection{Green Job Design}

Job design is an employee motivational process that increasesemployee's productivity andmakes more attention to do the job. Some of the organizations design the job to protect the environment. Many organizationhasemployed environmental based duties and responsibilities to protect the environment and make it friendly(Stojanoska, 2016). Focus on environmental dimension tasks and duties to practice green HRM that make the organization sustainable.

\subsection{Green Human Resource Planning}

Currently, many organizationdecide to recruit or ask for the job seekers who are an eco-friendly and environmental concern. Organizations are more interested in making a member of the eco-friendly employees to implement corporate environmental management programs (Stojanoska, 2016). It is possible to plan and execute such a way of engaging more and more employees towards the organization who have green concern mentality.

\subsection{Green Recruitment and Selection}

The organization that practices the green HRM activates, they have a unique or a general policy of their own. Every organization has a different strategy for the requirement process. In green recruitment, organization uses the green recruitment manner and focus on the environment-oriented employees. Because, creating an environment oriented organization and turn the workforce towards them, green recruitment plays a very authentic role. Environmental issues have to embrace recruitment advertisements(Arulrajah et al., 2015). Because the organizations need the best green recruitment practices(Stojanoska, 2016). For that reason, to attract eco-friendly people for the job vacancies, job advertisements of the organization have to include the environment related issues that the organization practices. And most importantly, when selecting the candidates for the position it is must to evaluate and judge by environment-related issues/questions while interviewing or examining them (Crosbie \& Knight, 1995).

\subsection{Green Training and Development}

Employee training and development is a pivotal function to make the organization effective and efficient. Proper training and development increase the production of the company. It develops the employee's knowledge and skills of the organization. In the same way, to promote the environmental skills and understanding of the employees, the organization should provide environmental training to the organization's human resources. The environmental practice is very supportive for the organization and helps to minimize the negative environmental impacts of the organization as well as encourage to recycle and waste management process (Jackson, Renwick, Jabbour, \& Muller-Camen, 2011).At present, the organizations are assigning opportunities to all to be trained as environmental aspects and developing their skills and knowledge about greening for ensuring proper environmental management and organizational sustainability. 


\subsection{Green Performance and Reward Management}

Many organizations have evaluated employee performances by their environmental performance. A research paper suggests that organizations must establishanEnvironmental Management Information System (EMIS) and environmental audits to sustain good performance management (Arulrajah et al., 2015). Another researcher said that the managers need to formulate some green related targets, goals, and responsibilities in their job toeasily evaluate their performance (D. W. Renwick, Redman, \& Maguire, 2013). It is a critical function in green HRM to assess the employee green performance. No organization can be able to ensure this holistic environmental performance in a sustainable manner. Regular feedback, good management practices can make it a success.

On the other hand, green reward management depends on the green performance evaluation of the employees. Performance management is an important function to make the organization profitable as well as sustainable. Organizational sustainability highly depends on the employee's satisfaction. Reward management can be practised in both financial and non-financial way. Money is a great prize for motivation (Govindarajulu \& Daily, 2004). Some organizationsalso provide a non-financial reward such as awards, recognitions, honours, accolades, leaves, gifts, publicity etc. (D. Renwick, Redman, \& Maguire, 2008). Opatha (2013) suggested giving extrinsic rewards such as admirations and acknowledgement to human resources for their Greening. Hence, employees become more motivated for doing the job by getting on their performance feedback.

\subsection{Green Safety Management and Employee Relation}

Each organization's performance, productivity and profit depend on the employee's effort towards the organization's goal and objectives. So it is very much impartment to ensure asafe and healthy workplace and good relation among them with management. Employees are not only motivated by the monetary value but also they deserve a safe and supportive as well as a friendly environment to do the job. So, employees will be more interested to work in the organization if the workplace will be eco-friendly as well as green. Because people love it, people love nature. And the green workplace is that workplace where the place is designed with environmental manner (SHRM, 2009) and indeed many construction companies, garments, manufacturing companies develop the strategies and maintain various policies to prevent the employee's health problem.

And most importantly organizations have to give the chance or opportunities to the employees to develop them, to utilize their skills and knowledge, to participate them for organizational decision making, to make them union representative, to engage them for problem-solving and so on. It also assists to operate the organization smoothly and make it sustainable. Many researchers are suggested to build a green relation with the employees and involve them in different green matters (D. W. Renwick et al., 2013).

\subsection{Green Business}

Every year near about 5\% green businesses have been growing during last three years (Mandip, 2012).There have many procedures and activities for going green business. It 
includes eco-friendly activities that prevent and minimize the wastage of the organization, concern about the employees, society, and so on. The green business intends to reduce the negative and harmful impact on the environment. As a greenbusinesshasthe various process, but to green business, the company should participate at least one of "4Rs", viz. reduction, reuse, recycling, and recovery (Kassaye, 2001). So achieving these " $R$ ", there have numerous green activities. Some everyday'sactivities that have discussed in the previous researches are as follows:

- Natural commodities or products

- Renewable products

- Green building

- Reducing uses of plastic

- Reducing power waste

- Green HRM

- Energy saving

- Eco-labelling

- Less use of raw materials

- Green packaging

- Green distribution and promotion

- Green customer services

- Waste management

- Green research and development

- Green accounting and financing

Green business is a set of multidimensional process and activities where the organization can follow various practicesto become green and sustainable (Covin, Green, \& Slevin, 2006). The organizationbecomes more highlighted byutilising the green process in the organization. As the organization become concern about the environment and take holistic approaches for protecting the earth from the damages, the stakeholders become more loyal and grateful towards the organization. It is beneficial to become greener for organizational sustainability.

\subsection{Organizational Sustainability}

This is the era of competition as well as the business competition. There have numerous products are available what we want. Many organizations incorporate in everyday and operate their business nationally and globally. But are all the businesses sustain and can compete with their competitors? Maybe the answer is negative. Because all the organizations haven't followed the same strategy and can't achieve competitive advantages equally. So, it is essential to ensure the organization sustainably. Because according to the Involvement and Participation Association (2011), that "we are entering the age of sustainability"(CIPD, 2012).

So, what is organizational sustainability? Many researchers have defined sustainability as "keep the business going", "future proofing" (Colbert \& Kurucz, 2007), "achieving success today without compromising the needs of the future" (Boudreau \& Ramstad, 2005). And organizational sustainability is a long term business operation that "the principle of 
enhancing the societal, environmental and economic systems within which a business operates" (CIPD, 2012).Hence, business functions are plays a crucial role to make an organization sustainable.

On the other hand, a previous paper stated that achieving the organizational sustainability and goal human resource plays an important role to implement the organization environment policy(Govindarajulu \& Daily, 2004). So, green human resource management is undoubtedly the process that helps to perform managerial objectives to the HRM process of staffing and selection, training, and, developing, performance appraisal and rewarding for environment sustainability(D. Renwick et al., 2008). Where the primary aim of the green HRM is to ensureaugment and maintain greening within every employees and employer of the organization to promote organizational as well as environmental sustainability (Wehrmeyer, 2017). Green Human Resource functions are indispensable to ensure organizational sustainability. It also keeps the organization's environment safe and nontoxic. Because through practicing it's function and policies it will become the manger to sustain the organizational sustainability as well as the environment of the organization (Mandip, 2012).

To ensure a sustainable organization, it is very much essential to establish or develop or restructure the business with green manner. Because only green HRM is unable to make the organization sustainable if the organization may heavy productive or constructive or manufacturing types that hamper or damage the environment. Green business is an eco-friendly practice of business activities that donnot have adverse effects on the environment where green HRM is a set of functions of organization's management team that help to operate the business with green effective and efficient manner. Hence, ensuring the organization's sustainability then both green business and green HRM have to perform together.

\section{Proposed Model for Sustainable Organization through Green HRMand Green Business}

Organizational sustainability is essential for each organization. Every organization wants to achieve its goals and objectives and want to operate for going concern. So, it is possible by using proper green HRM practices and holistic green business functions. Many organizationgives the tax benefits, case benefits, wastage management facilities, and so on because of thinking about their stakeholders(Mandip, 2012). There are so many research scholars supported in many function of HRM practices to make organizational performance and more effective(Boselie, Paauwe, \& Jansen, 2001). Hussain also suggested a model for practicing Green HR and their potential consequences in the organization(Hussain, 2018). 


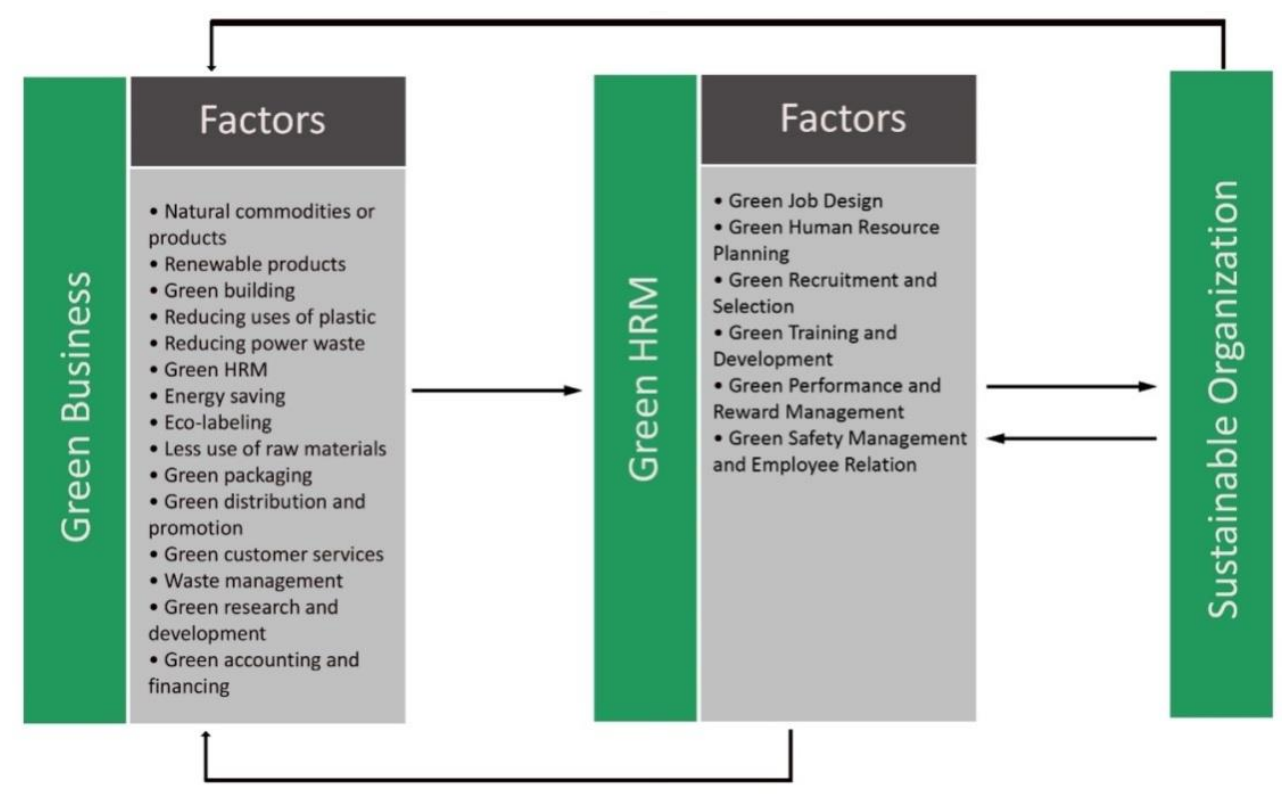

Figure 1. Model of Sustainable Organization through Green Business and Green HRM

\section{Source: Developed by the Authors}

In the era of business, there have lots of organizations who are doing business with huge number of products. From the production to consumption the organization needs various stages to produce consumable goods. While in the process of producing goods the organizations assemble a lot of wastes and trashes which are very much harmful for human being as well as the environment. For making an organization green the organization need to follow green business manner. So, to make business green, business have to conduct with natural commodities or products, renewable products, green building, reducing uses of plastics, reducing power waste, green HRM, energy saving, eco-labelling, less use of raw materials, green packaging, green distribution and promotion, green customer services, waste management, green research and development, green accounting and financing etc. And after that it should follow the green HRM practices i.e. green job design, green human resource planning, green recruitment and selection, green training and development, green performance and reward management, green safety management and employee relation for making that business as well as organization sustainable. The first phase's factors consist of various contents that help to formulate green business. And second phase's factors consist of the contents of green HRM practices. Unless the second phase won't use properly then the first phase won't be effective properly. Following both of these phases could be made the organization sustainable. The proposed model can be useful for ensuring the organization sustainable by the indemnity of proper green business functions and green HRM practices. That will give feedback to each other and can grow up strategically.

\section{Conclusion}

From the above discussion, we can see many reasons to go green and there have no alternative for ensuring organizational sustainability without both green business and green 
HRM too. Green HRM; Green Job Design, Green Human Resource Planning, Green Recruitment and Selection, Green Training and Development, Green Performance and Reward Management, Green Safety Management and Employee Relation, and Green Business together can make the organization sustainable. All the green business functions and green HRM policies and activities are essential cooperatively for making a sustainable organization. The green business will ensure the eco-friendly organization and green HRM will help to reduce the harmful eco-impacts of the organization and mend the organization's performance. Green HRM will focus on the essential key resource viz. people of the organization and the people will help to achieve the green business goals and objectives through their loyal participation. Proposed model will help to ensure an organizations' sustainability too.

Green business is most demandable as well as a holistic approach not only to the individual but also in the today's organization around the world. The world badly needed green business functions to prevent and protect from the damages. Based on the whole discussion, it can be concluded that green business and green HRM can increase environmental performance together in a more sustainable way for the organization as well as for the earth. As it is tough to understand, utilize, and operate both green business and green HRM together, but it is not impossible if people want to remake the earth as well as the organization sustainable.

\section{Acknowledgement}

We would like to thank to the previous researchers who have scrutinized on the issues of green business, green HRM practices and sustainability.

\section{References}

Adger, W. N., Dessai, S., Goulden, M., Hulme, M., Lorenzoni, I., Nelson, D. R., ... Wreford, A. (2009). Are there social limits to adaptation to climate change?.Climatic change, 93(3-4), 335-354.https://doi.org/10.1007/s10584-008-9520-z

Agarwal, P. (2014). Role of the HR Professionals in Environmental Management.VIMARSH, 22.

Aravamudhan, N. (2012). getting into the Business of Green. HRM Review, 12.

Arulrajah, A. A., Opatha, H., \& Nawaratne, N. (2015). Green human resource management practices: A review. Sri Lankan Journal of Human Resource Management, 5(1).https://doi.org/10.4038/sljhrm.v5i1.5624

Aykan, E. (2017). Gaining a Competitive Advantage through Green Human Resource Management. In Corporate Governance and Strategic Decision Making: IntechOpen. https://doi.org/10.5772/intechopen.69703

Bombiak, E., \& Marciniuk-Kluska, A. (2018). Green human resource management as a tool for the sustainable development of enterprises: Polish young company experience. Sustainability, 10(6), 1739.https://doi.org/10.3390/su10061739

Boselie, P., Paauwe, J., \& Jansen, P. (2001). Human resource management and performance: 


\section{Macrothink}

Environmental Management and Sustainable Development

ISSN 2164-7682

2019, Vol. 8, No. 3

lessons from the Netherlands. International journal of human resource management, 12(7), 1107-1125.https://doi.org/10.1080/09585190110068331

Boudreau, J. W., \& Ramstad, P. M. (2005). Talentship, talent segmentation, and sustainability: A new HR decision science paradigm for a new strategy definition. Human Resource Management: Published in Cooperation with the School of Business Administration, The University of Michigan and in alliance with the Society of Human Resources Management, 44(2), 129-136. https://doi.org/10.1002/hrm.20054

Chettri, S. (2018). An Analysis of Climate Induced Health Impacts in Sikkim Himalaya, India. https://doi.org/10.2139/ssrn.3176430

CIPD. (2012). A Collection of Thought Pieces-Responsible and Sustainable Business: HR Leading the Way. In: London, UK: CIPD.

Colbert, B. A., \& Kurucz, E. C. (2007). Three conceptions of triple bottom line business sustainability and the role for HRM. Human Resource Planning, 30(1), 21-30.

Cooney, S. (2009).Build a green small business: Profitable ways to become an ecopreneur: McGraw-Hill.

Covin, J. G., Green, K. M., \& Slevin, D. P. (2006). Strategic process effects on the entrepreneurial orientation-sales growth rate relationship. Entrepreneurship theory and practice, 30(1), 57-81.https://doi.org/10.1111/j.1540-6520.2006.00110.x

Crosbie, L., \& Knight, K. (1995).Strategy for sustainable business: environmental opportunity and strategic choice: McGraw-Hill Companies.

Croston, G. E. (2009). Starting green: An ecopreneur's toolkit for starting a green business-From business plan to profits: Entrepreneur Press.

Das, S. C. K. S., Raj. (2014). Green HRM: Practices and strategic implementation in the organizations. International Journal on Recent and Innovation Trends in Computing and Communication, 2(11), 3633-3639.

Das, S. C., \& Raj, K. S. (2016). Green HRM and Organizational Sustainability: An Empirical Review. Kegees Journal of Social Science, 8, 227-236.

Gain, A. K., Giupponi, C., \& Wada, Y. (2016).Measuring global water security towards sustainable development goals.Environmental Research Letters, 11(12), 124015.https://doi.org/10.1088/1748-9326/11/12/124015

Govindarajulu, N., \& Daily, B. F. (2004).Motivating employees for environmental improvement.Industrial management \& data systems, 104(4), 364-372.

https://doi.org/10.1108/02635570410530775

Green, C. (2011). Green Business Definition and Opportunities (2011).In.

Herring, H. (2000). Is energy efficiency environmentally friendly? Energy \& Environment, 11(3), 313-325. https://doi.org/10.1260/0958305001500167 


\section{Macrothink}

Environmental Management and Sustainable Development

ISSN 2164-7682 2019, Vol. 8, No. 3

Hussain, A. (2018). Green Human Resource Management (GHRM) Practices in Organizations: A Comprehensive Literature Survey.

Jackson, S. E., Renwick, D. W., Jabbour, C. J., \& Muller-Camen, M. (2011). State-of-the-art and future directions for green human resource management: Introduction to the special issue. German Journal of Human Resource Management, 25(2), 99-116.

https://doi.org/10.1177/239700221102500203

Kassaye, W. W. (2001). Green dilemma.Marketing intelligence \& planning, 19(6), 444-455.https://doi.org/10.1108/EUM0000000006112

Lee, K. (2008). Opportunities for green marketing: young consumers. Marketing intelligence \& planning, 26(6), 573-586.https://doi.org/10.1108/02634500810902839

Mandip, G. (2012). Green HRM: People management commitment to environmental sustainability. Research Journal of Recent Sciences, ISSN, 2277, 2502.

Rao, V. V., Mathapati, S., \& Amarapur, B. (2013). Multiple power supplied fertilizer sprayer. International Journal of Scientific and Research Publications, 3(8), 1.

Renwick, D., Redman, T., \& Maguire, S. (2008). Green HRM: A review, process model, and research agenda. University of Sheffield Management School Discussion Paper, 1, 1-46.

Renwick, D. W., Redman, T., \& Maguire, S. (2013). Green human resource management: A review and research agenda. International Journal of Management Reviews, 15(1), 1-14. https://doi.org/10.1111/j.1468-2370.2011.00328.x

Stojanoska, A. (2016). Green human resource management: the case of Gorenje group. Univerza v Ljubljani, Ekonomska fakulteta,

Wehrmeyer, W. (2017).Greening people: Human resources and environmental management: Routledge.

\section{Copyright Disclaimer}

Copyright for this article is retained by the author(s), with first publication rights granted to the journal.

This is an open-access article distributed under the terms and conditions of the Creative Commons Attribution license (http://creativecommons.org/licenses/by/3.0/). 